This item was submitted to Loughborough's Research Repository by the author.

Items in Figshare are protected by copyright, with all rights reserved, unless otherwise indicated.

\title{
Understanding operations strategizing in project-based organisations: middle managers' interaction and strategy praxis
}

PLEASE CITE THE PUBLISHED VERSION

http://dx.doi.org/10.1080/21573727.2015.1048682

\section{PUBLISHER}

(C) Taylor \& Francis

\section{VERSION}

AM (Accepted Manuscript)

\section{PUBLISHER STATEMENT}

This work is made available according to the conditions of the Creative Commons Attribution-NonCommercialNoDerivatives 4.0 International (CC BY-NC-ND 4.0) licence. Full details of this licence are available at: https://creativecommons.org/licenses/by-nc-nd/4.0/

\section{LICENCE}

CC BY-NC-ND 4.0

\section{REPOSITORY RECORD}

Koch, Christian, Daniel J. Sage, Andrew R.J. Dainty, and Rolf Simonsen. 2019. "Understanding Operations Strategizing in Project-based Organisations: Middle Managers' Interaction and Strategy Praxis". figshare. https://hdl.handle.net/2134/18290. 


\section{Understanding operations strategizing in project-based organisations: middle managers' interaction and strategy praxis}

\section{Abstract}

The study of operations strategy in production organisations has largely focused on the content of high-level strategies, and less on their practical enactment. Little attention has been paid to the middle managers who mediate the space between the strategic intent of production organisations and their operational realities. The role and strategic agency of such managers has been shown to be influential in shaping, impeding and enabling operations strategy, but they remain surprisingly absent from much project organisation literature. In this paper we examine the role of middle managers in operations strategy practice via a Strategyas-Practice framework. We study two project-based organisations, one in Denmark and one in UK, developing lean production processes. In the Danish case the change strategy was initiated bottom-up from the project actors, whereas in the UK, the change strategy was imposed top-down as a strategic management initiative. In both cases middle managers played a crucial role in mediating and translating intention. We show how strategy praxis, and the leadership of operations, is highly distributed within project-based organisations regardless of where change is initiated from. The findings have resonances for theory on the agency of middle managers, and for the understanding of micro activities of operations strategy formulation and implementation within project-based forms of organisation.

Keywords: Strategizing, operations strategy, middle managers, construction contractors 


\section{Introduction}

Operations Strategy (OS) approaches have been seen as largely irrelevant to project-based organisations, given their focus on low variety/high volume (manufacturing) operations (e.g. Hayes and Wainwright, 1984; Skinner, 1969). Yet recently there have been attempts to develop OS approaches for project-based organisations (Maylor et al. 2014); this work suggests that at a theoretical level at least, OS can enhance the performance of project-based organisations. But questions remain as to how such strategy processes are enacted within complex, temporary environments. Regrettably, the extant OS literature has tended to focus on OS content rather than the process of its enactment (Rytter et al. 2007) or indeed the relationship between the two. Meanwhile the process models that do exist are prescriptive in orientation, and disconnected from organisational realities (Boyer et al 2005). Responding to this situation our aim in this paper is to contribute an empirical examination of an OS enactment within project-based organisations. Developing empirical insights into the processual aspects of OS demands an approach which reveals the nature of the situated practices which surround it, and within which OS can be viewed as an ongoing social accomplishment (Sage et al. 2012). Strategy as practice (SAP) offers such a lens by directing attention towards the strategy practitioners (those making and executing strategies), the strategy practices, the predominantly extra-organisational, but also intraorganisational routines that practitioners draw upon in their praxis, and strategy praxis (what practitioners actually do in designing, shaping and implementing strategies) (Helkiö 2013; Rouleau 2013; Whittington 2006). SAP allows the sectoral and societal issues that have influence on the OS development to be examined, revealing something of the relationship between what goes on deep within the organisation and the broader external phenomena under consideration (cf. Whittington 2006). 
To develop our analysis we chart the development of an operations strategy originally associated with high volume production environments - lean production - within a construction context. First introduced by Koskela (1992), lean construction comprises a group of tools and philosophies for planning and executing construction projects (Simonsen 2007). It spans the supply, design, and production of buildings (Ballard 2000) and focuses on reducing waste and maximising value through tools such as The Last Planner System (Ballard 2000), seven healthy streams or flows, and Percent Planned Completed (PPC); these tools measure performance to help schedule and coordinate, production. Lean also encompasses a philosophy: employees within a construction organisation, and its supply-chain, are encouraged to be more actively involved in identifying value and minimizing waste, around an ethos of continuous improvement (cf. Womack and Jones, 1996).

Analytically, we focus on a particular group of strategy practitioners associated with Lean construction, namely middle managers and their praxis. Within the wider SaP community a small number of studies have addressed middle managers as mediators of strategy (see Mantere, 2008; Sillince and Mueller, 2007; Thomas and Ambrosini, 2015), but seldom in relation to project-based organisations. Our research focus and contribution: on middle managers is thus motivated by both their recognized significance middle managers in strategic implementation (Balogun and Johnson 2004, Rouleau and Balogun, 2010, Mantere, 2008; Floyd and Wooldridge 1994) as well as the importance of middle managers as agents of control within project-based organisations, not least construction (Styhre and Josephson 2006). Our purpose here, and key contribution, is to thus develop a SaP informed analysis of how middle managers mediate operations strategies, such as Lean, across project-based organisations, extending and focusing previous studies on more general business strategy at contractors (Betts and Ofori 1992, Cheah and Chew 2005, Cheah and Garvin 2002, Junnonen 
1998, Kao et al 2009,Löwstedt and Räisänen 2014). Moreover, by focussing on the praxis of middle managers as mediators of strategy our analysis develops extant research on strategizing in project-based organisation such as construction, where despite some calls (e.g. Green et al. 2008: 76) strategy research has tended to focus on the planning (e.g. Cheah et al., 2007; Russell et al. 2014; Stewart and Spencer, 2006) rather than the doing of strategy. This focus on doing strategy posits our contribution in prolongation of that provided by Räisänen \& Löwstedt (2014) and Sage et al. (2012). This perspective is important, not least because 'preparing practitioners better for entry into strategy praxis should help middle managers and others contribute more effectively to their organizations' strategizing' (Whittington, 2006: 627).

The construction project management literature defines middle management variously. For Styhre and Josephson (2006) site managers are middle managers as they operate between strategic decisions and production work. Contrastingly, Kissi et al. (2013) define middle managers as ‘portfolio managers' overseeing projects led by different project managers which are not necessarily interrelated. In recent years 'programme management' has also emerged as a term to describe such managers that "bridge the gap between project delivery and organisational strategy” (Lycett et al. 2004). However, what connects all such managers is that they mediate the space between the strategic decision making environment and front-line operations. Hence, we define middle management to include programme/portfolio managers, project directors, key account managers, contracts managers and department managers, support service managers, project and site managers. Together they shape the strategy implementation process; whether it be gathering and developing operationally defined strategies, or translating strategic managerial intent through the operating line of the organisation. 
Our paper presents a comparative analysis of both top-down and bottom-up approaches to an OS. We begin by establishing a theoretical framework for the paper before explicating the case study-based methodology, results from the Danish (DK) and United Kingdom (UK) case studies which follow characteristically different paths and the implications for understanding operations strategy in project-based organisations.

\section{Theorising operations strategy in project-based organisation}

The contribution of this paper lies at the intersection of four separate but interrelated areas of research: OS; construction as a project-based industry; SAP (strategy practice, praxis, practitioners and implementation as a translation process); and middle management agency. These four areas contributes to our framework in characteristically different ways: OS is the type of strategy that we focus on, SAP is our theoretical interpretive frame, wherein middle managers agency is cast as strategy practitioners and construction as project-based poses characteristic barriers and enablers. Each of these four areas is reviewed below in order to set out a theoretical frame of reference for the analysis:

\section{Operations Strategy}

The operations-, manufacturing-, and technology-management literature encompasses concepts of operations strategy and manufacturing strategy (Maylor et al 2014). The study of 
OS in manufacturing organisations represents a long-standing research focus, with a special interest in the relationship between organisational capabilities, resources and routines, and the achievement of performance goals (Anand 2009; Hayes and Wheelwright 1984; Skinner 1969). Operations and manufacturing can be overarched by the OS concept, to convey:

... the total pattern of decisions which shape the long-term capabilities of any type of operations and their contribution to overall strategy, through the reconciliation of market requirements with operations resources (Slack and Lewis, 2008, p. 18).

As with business strategy research (De Wit and Meyer 2010), where the content focus reigns, OS content - dealing with how operations can create competitive advantage by providing normative guidelines on what to include (see Anderson et al. 1991) - remains the research focus. The smaller number of strategy process approaches deal with how to conduct OS formulation and implementation processes (Barnes, 2001, Rytter et al. 2007). Notwithstanding calls for more strategy processes research (Dangayach and Deshmukh, 2001; Boyer et al., 2005; Rytter et al., 2007), most process contributions remain prescriptive and abstract from the empirical realities of OS processes (Barnes, 2001, 2002). Consequently, OS is frequently presented as a linear, analytical and rational process of top-down formulation and implementation activities (Leong 1990). New empirical insights are required which explore the actuality of OS enactment, not least within project-based organisations such as construction. 


\section{Construction as a project based industry}

Construction is a project-based industry: temporary, multi-firm, projects are the organisational vehicle for carrying out the design and production of buildings (Kentaro and Cusumano, 1998). In construction projects a mixture of production and product development occurs as the building progresses. As such, construction project work always involves an element of (new) product development. Indeed, the industry tends to celebrate the uniqueness of the single product and production project delivered and the human resource constellation employed, and downplays stable and repetitive elements. So bespoke is the output of most of what the industry produces that even engineer-to-order supply chain principles require adaptation to account for the uniquely complex environment that characterises construction projects (Gosling et al. 2014), contrasted to the stable, repetitive projects typical of other production contexts (Maylor, 2010).

The imperative for innovation and efficient production renders construction an especially interesting context within which to develop OS. Construction contractors can be described as confronting a set of contradictory pressures (Ekstedt et al., 1999; Koch, 2004). Structurally, contractors tend to be squeezed on price not only by the clients, but also by component manufacturers attempting to add value to their product by offering various services to their product. Organisationally, project resources and tasks (inputs) must lead to output, generating demands for efficient production. Within project teams, multi-disciplinarity, the product of subcontracting and the push for efficiency also engender challenges in coordinating, learning and innovating across multiple organisational boundaries (Kentaro and Cusumano, 1998). Individually, professionals are continually expected to embrace a shifting body of knowledge 
of work practices, statutory norms and regulations, basic education and vocational training (Dent and Whitehead, 2002, Hodgson, 2002), alongside that required to learn competencies related to cross-disciplinary communication, problem-solving and coordination. It should thus be expected that such dynamic project-based organisations exhibit different operational contexts, and projects, from more stable sectors, like manufacturing. What is more, the dynamics of projects intersect with the dynamics of the project-based company and the surrounding environment (Winch 1998); this milieu impacts on the extent to which particular OS ideas aligns (or not) with managerial and other interests and perspectives. The translation of knowledge of practice (OS content) is one important aspect determining this process.

\section{A SAP framework for studying operations strategizing}

The strategy as practice (SAP) perspective departs from a range of content-based perspectives on strategy by focusing on the notion that strategy is not something you have but something you do (Mintzberg and Lampel, 1999; Whittington, 2001, 2006). While most strategy approaches include identifiable strategy practices (for example Porter, 1980) and a view on strategy practitioners (for example Pettigrew 1985), SAP provides “a strongly advocated research agenda into strategy practices” (Jarzabkowski and Spee, 2009:82, see also Rouleau 2013). The SAP perspective underscores the position that strategy practitioners make strategy by exercising practices in a more or less reflective manner, using strategy tools to shape and enact strategy, and these are very relevant components in getting closer to the doing, or praxis, of strategy. According to Whittington (2006), strategy praxis corresponds to the observed and felt activities of strategy - praxis can be viewed as a stream of such activities over time (Jarzabkowski and Spee, 2009), including decision-making, planning, issue-selling, 
analyses and the creation of objectives. In other words, it reflects both the formal and informal work of making strategy. By contrast, strategy practices are those "shared routines of behaviour, including traditions, norms and procedures for thinking, acting and using 'things'” (Whittington, 2006: 619) that guide actual praxis. Practices can take the form of social, material, and operation procedures, such as heuristics, scripts, routines and languages (Omicini and Ossowski, 2004). SAP scholars note the embedded and institutionalized nature of practice (Jarzabkowski and Spee, 2009; Whittington, 2006), which provides a shared understanding of how to do strategy, material practices, tacit 'know-how' and the habitual modes of doing strategy such as reviews, meetings and off-site days, all of which are shared and recognized ways of 'doing' strategy (Hodgkinson et al., 2006). Strategy practitioners, not least middle managers, are the actors who draw upon strategy practices to act in strategy praxis. They derive agency through their use of practice and praxis - ways of behaving, thinking, knowing and acting, combining, coordinating and adapting these 'ways' to their needs in order to act (Reckwitz, 2002).

\section{Middle managers}

Middle managers are key members of organisations, especially in relation to the role they play as mediators between the strategic apex and the remainder of organisation (Balogun and Johnson 2004, Balogun and Rouleau 2010, Mantere, 2008; Floyd and Wooldridge 1994). Intriguingly, most studies of strategy remain focussed on senior management, from SAP studies (Jarzabkowski and Spee 2009, Rouleau 2013) to those looking at the impact of transformational leadership in organisational performance (e.g. Jung et al., 2003, 2008; Sarros, et al., 2008). Of the studies that have examined the role of middle managers in 
strategy enactment, Mantere’s (2008) work is notable for opening up new understandings of the ways in which middle management agency shapes strategy beyond functionalist approaches. Balogun and Johnson (2004) also reveal the important role that vertical mediation and lateral interaction by middle managers plays in strategy implementation. However, although these studies have begun to reveal the enabling role played by middle managers in formulating and implementing business strategy, they predominantly look on top-down strategy and on industries with regular hierarchies whereas strategy practices and praxis and the ways in which it is intertwined with their negotiated agency as strategy practitioners in OS and in project-based organisations is less theoretically developed.

\section{A framework for understanding operations strategy in project-based organisation}

We focus now on the processes of doing OS strategy in project-based (construction) organisations. The particular strategy studied here is lean construction, conceptualized as a strategic practice, upon which translation processes are carried out by strategy practitioners situated in both temporary project and more stable organisational settings creating a praxis of translated lean construction elements. In our case context, construction projects are seen as the production units. What unites our cases is that the development of new content in OS involves processes of engaging with the project operations teams, middle level managers and top level management. Vertical decoupling, between projects and company offices, is significant within construction and yet the process of strategy content change is dependent on enacting the strategy across these hierarchical boundaries, as well as boundaries between organisations. In particular, processes of negotiating the strategy content - changing it to accommodate diverse interests - become crucial. Our approach avoids simplistic portrayals of strategy as an inert 
commodity circulating and organizing others without undergoing any transformation itself (Bresnen et al., 2002). This is why we choose to focus on the translation of strategy practices into praxis through the mediation of middle managers as strategy practitioners: these practitioners are likely to play a crucial mediating role in both vertical (hierarchical) and horizontal (intra-organisational) terms.

\section{Research methods and cases}

We adopt an interpretive approach (Johnson et al 2010), using SAP as our theoretical touchstone, combined with contributions from OS process approaches (Barnes 2001, 2002). SAP research demands a careful consideration of the research process if the situated and emergent nature of strategizing is to be comprehended (cf. Jarzabkowski et al., 2007, p. 22). Rasche and Chia (2009) suggest that SAP perspectives should juxtapose traditional research methods (e.g. structured interviews and questionnaires) and documentary analysis with ethnographic observation. Unlike interviews, observations enable researchers to understand how everyday practices (such as moving, gesturing, facial expression, tone of voice etc.) and dynamic material interactions (with Power-Point, Desks, Forms, Scorecards, Plans etc.) shape the craft of strategy.

Using these methods, we explore lean strategy within two case study organisations. Each offers a potentially unique opportunity to explore OS in project-based organisation (Stake, 2000). One case is based on a major, privately owned contractor in the UK (anonymous), and the other a similar sized organisation based in Denmark (anonymous). Although the two cases 
operate within very different national contexts, and the two studies were carried out independently, the research team found in their initial dialogue that they share a common feature in that they both operate in a market where lean construction was promoted and legitimized as an OS. Our cross-case analysis is thus designed according to learn from rather than strictly comparing the cases (Stake 2000) However, although the organisations share a desire to improve performance through more or less the same OS content, the OS process differs significantly: one seeks to translate lean into praxis through high-level policy, while the other through grassroots operational innovation within projects. What joins these cases is the centrality of middle managers in formulating, mediating, shaping and implementing the eventual strategies. Methodologically, the data was transcribed and analysed separately by two research teams, one in the UK and one in Denmark. In a sequential and synergistic manner the research then exposed this original material to a new round of analysis with a juxtaposed theoretical framework (Lewis and Grimes 1999) using an intercollegiate process to scrutinize the material and previous interpretation. Comparative analysis of the data from these two initially independent research studies was prompted due to their similarity and difference drawing on Stake (2000). The cases are similar in terms of their common strategic practice - lean construction - yet they differ due to the praxis involved, namely the organisational level at which this strategy was initiated and diffused within each organisation. But with each case our attention was drawn variously to the role of middle managers as important mediators of strategizing and in particular within project-based organisations. This second analysis was enabled by the open and elaborate character of the documented and transcribed ethnographic studies (author references).

\section{The UK case}


The data on the UK contractor, hereafter called UKCO, were gathered over a period of 12 months (during 2008-2009) within a wider two year research project examining perspectives on project failure and success. During the research project UKCO was implementing a lean construction improvement strategy, largely in response to an industry-driven reform agenda (Egan 1998) where lean was advocated as a route to step-change improvements in performance. Data were collected from UKCO across numerous visits to the company's headquarters and visits to six project sites. The data gathered in this paper include six observations of weekly planning meetings, planning documents, lean policy statements and 26 semi-structured interviews with project practitioners including site managers, project managers, regional construction managers, audit managers and the UKCO Lean Champion (Business Process Improvement Manager). Observational data were recorded through field notes made by one of the authors. Documents gathered included corporate reports, strategy pamphlets, training documents, project plans and site meeting minutes. Interviewees were asked a variety of questions concerning their role in UKCO, their experiences of their current project and more general questions about the changes within UKCO including the lean improvement programme. Interviews were recorded and later transcribed.

\section{The Danish case}

The data for the Danish case was collected through a longitudinal processual case study conducted as part of one of the author's doctoral project into the focus on the political processes (cf. Pettigrew 1985) of implementing lean construction. The analytical design carried out here is a further iteration of the abductive approach of the doctoral study (Dubois 
and Gadde, 2002). The case concerns a major building contractor operating in Denmark, a project-based organisation concerned with a large number of concurrent construction projects, including some design work. This contractor was selected because it was about to commence the implementation of lean. The empirical fieldwork constituted 14 qualitative interviews, conducting at different management levels in the organisation of the contractor to capture the strategic decisions regarding the implementation of lean. Additionally, within two building projects, 11 interviews with project managers and sub-contractor foremen and seven participatory observations of weekly planning meeting were also conducted, in order to understand the implementation of lean.

In both studies we included the extra-organisational context and role in the lean strategizing, however we have chosen here to focus on the company internal dynamics, which is a limitation.

\section{Findings}

\section{The UK case}

The CEO of UKCO was a passionate, self-taught, proponent of lean thinking: he was familiar with various books on the subject, including those of Womack and Jones (e.g. Womack and Jones, 1996). And he encouraged the use of lean from day one of his appointment as CEO in 2006. The implementation of lean in UKCO, indeed within UK construction, was not 
especially new: since Sir John Egan’s government report into the industry a decade earlier (Egan, 1998) lean has been advocated as a change recipe to combat various interlinked problems associated with UK construction from low innovation to an adversarial working culture. UKCO’s lean strategy was linked with its supply chain, and the development process included the creation of a series of values - the 'UKCO values', adapted from the 14 lean ideas, including continuous improvement (Kaizen) and empowerment, crystallized in the 'Toyota Way' (cf. Liker, 2004). The CEO also selected a range of more substantive mechanisms to develop a lean strategy; these included: the appointment of a business improvement manager trained in the Last Planner System, a range of new standardized documentation (including visual controls), a management improvement programme and the use of collaborative weekly planning workshops.

In October 2007 a lean process improvement manager (the 'Champion') was asked by the CEO to 'get collaborative planning across all the sites'. As the Champion explains, this process was ‘our version of Last Planner, we didn’t call it Last Planner but that's essentially what it was'. However, UKCO's version of collaborative weekly planning, a focal point of the Last Planner System, was modified insofar as the requirement for PPC was not mandated across all sites; thus on many sites a simply tick box could be used for work being 'on time' or 'snag free'. Standardized 'Weekly Plan' forms were also sent to each site to guide these weekly collaborative meetings with site managers and sub-contractor managers. As these meetings were becoming embedded in sites by early 2008, the CEO, Champion and human resource department at UKCO decided to hold a series of improvement workshops for each level of management. The purpose of these workshops was to situate the weekly collaborative planning meetings, and planning process standardization, of lean construction, in a wider cultural change towards collaborative, continuous improvement. As the Champion explains, 
lean is more than just collaborative planning: 'it's the processes we have, it's the people, it's the way they behave, it's about having the strategy, how we cascade that, how we make sure we're trying to innovate and get best practice'. The workshops were all run by senior managers for more junior, usually site-based employees, in order to encourage collaborative continuous improvement. One of these workshops was observed by a co-author of this paper and serves to show how UKCO's the strategic practices and praxis of middle managers mediated lean construction.

In May 2008, UKCO held its first line management workshop attended by site managers, assistant site managers and work supervisors (or 'foremen'). The workshop was facilitated by a regional construction manager and a human resource manager. The workshop consisted of related interactive exercises, wherein line managers were asked: 'why good and bad jobs were good or bad, and the reasons why' along with how they might 'recognize one early'. Many discussed ideas aligned well with lean's strategic content, from the positive need to 'sit together as a team once a week to sort out problems' to the delays created by low-level of coordination and collaboration. The regional construction director interjected: 'If we don't communicate, it will affect the whole company', 'a good manager should walk around site, and sit and have tea with you - why don't people do this?' and 'You cannot delegate if you have no standards, then how do they know what to do' And yet, the strategic practices of the workshop was strangely at odds with the collaborative content of lean, espoused by the CEO and Champion: the line managers did not discuss ideas with each other during the exercises but rather wrote in silence then fed ideas individually back to the facilitation team. Moreover, while the line managers repeatedly identified poor decision-making by senior manager as partly responsibility for creating waste (e.g. tendering for projects using inexperienced subcontractors and creating unrealistic budgets and schedules), the senior management 
facilitators refused to discuss their own practices. While the workshop was framed by a lean ethos of collaboration and continuous improvement, the facilitation team, of middle managers from headquarters, drew upon such highly hierarchical strategic practices when translating how this collaborative strategic content was to be understood, and translated into strategic praxis. In effect, emphasis was placed through strategic practices (institutionalized hierarchical power relations) influencing praxis (didactic processes of strategizing) by the facilitation team upon the collaborative continuous improvement between UKCO line managers and sub-contractors, not between UKCO line managers and managers at UKCO’s headquarters. Against this backdrop of hierarchical strategic practices, on their return to sites, the strategic content of collaborative continuous improvement was translated by line managers, more or less, into site-level problem solving:

the idea behind collaboration is to look at that target programme, to challenge the dates on it, and to understand as a team, as a whole team, how we are all going to work together to achieve that programme (UKCO site manager 1).

\section{The DK case}

A number of private entrepreneurs first advocated Lean Construction in the Danish construction sector in 1999 (Simonsen et al., 2004). The case company did not, however, engage with Lean Construction until the fall of 2002, because other strategic efforts, especially partnering were preferred (Partnering as described in Bresnen and Marshall, 2000). By 2002 a competing contractor had adopted lean construction in their operations for around 
three years. The first project using lean construction at the case company (called here 'DKCO') was initiated by an experienced project manager. It was made possible through the cooperation with a consulting engineering company. This alliance was established to carry out a demonstration project of partnering on a dormitory project, but the consulting engineer and the project and site managers of the contractors, thought it was a good occasion to test lean construction methods. The Last Planner System (Ballard, 2000) was introduced to the project managers and later to the subcontractor foremen. Ultimately, as the foremen became involved in fine scheduling of Last Planner a set of new praxises was developed, which worked so well that the project manager did not need to employ his own schedule, a plan he kept however as a backup.

The project manager describes the success through the degree of percent planned completed (PPC):

I had promised large red steaks to everyone on site, if we met the schedule, and got a good PPC, PPC ended at 92\% and we were finished several months ahead so I had to throw in some red wine as well (DKCO project manager)

DKCO project and site managers communicating internally about their success of using lean construction. However, at the corporate headquarters of DKCO, a large implementation of another OS was ongoing at the time focused on the headquarters role in planning and design. Effort and resources were increasingly allocated to this endeavour. The project managers from 
the first lean project kept on advocating their experiences, narrating their experiences at internal seminars. Two more projects adopting lean, and Last Planner, were then initiated by the project and site managers. These projects experienced less positive outcomes. Lean's prominence within internal communications declined. Instead, as a result of the Headquarter OS, a new corporate function was established (i.e a dedicated group, with an assigned manager with the specific service task of supporting the production projects, placed above the line managers in the hierarchy, but with little hierarchical power). The function was aimed at improving the planning and scheduling of projects.

One and a half years passed before the new support process became operational. After this time the corporate support function for scheduling turned toward lean construction after the other OS was acceptably embedded in the company. Over the next year the principles of lean construction and the Last Planner System were studied by the personnel of the support function. Representatives from the support function also joined a Danish network on lean construction principles. The first implementations supported by the corporate function of Last Planner on building projects were then trialled. During this time a new corporate strategy, involving industrial construction as operation strategy, was strongly conveyed to managers and employees. Lean construction was not a direct part of this strategy. Corporate management was reluctant to promote lean construction as a new major strategic decision; instead it was presented as part of industrial construction, but also formally sanctioned and introduced. From this point, all projects at a certain size were obliged to use Last Planner. Executives did not have significant understanding of the content of lean: the details of lean implementation were in the perception of top management handled by the manager of the corporate support function and his staff. 
At first, the group of support function members collaborated closely with the project managers of the lean construction 'pilot' projects. Practice based competences thereby became embedded in the group: the group could also now support project managers on other building projects on the use of lean; this group also conducted lean training sessions for project managers. The strategic praxis of the support function group focussed on Last Planner, omitting other elements of lean. Strategic praxis was often relatively informal: the support function group ‘coached’ project managers on site on lean methods. The support function decided not to produce a lean 'manual' in the belief that informal, ad-hoc, interactions were more effective. Gradually some building projects began using lean, although most continued to operate without it. The support group and the practitioners behind lean found support through their involvement in lean construction development events in Denmark, but its implementation in DKCO projects remained highly differentiated. Accordingly, the two projects studied carried in this period developed in two markedly different ways despite the use of lean principles. At this time, the amount of lean projects in DKCO began to be monitored, and grew to $40 \%$, increasing to $46 \%$ in the subsequent year. And then, other top level business strategy practitioners intervened - mandating a reorganisation of the company: the previous manager of the support group function was promoted and became a central actor in the organisational development, which could even be seen as a strengthening of the positioning of lean.

The new OS had thus become embedded in some aspects of strategic praxis, notably the support function office, and yet it occupied a subordinate position in the content of the business strategy. On site, the use of lean was highly differentiated corresponding with the 
degree of involvement of the support function. From the studied projects it appears that the Last Planner meetings combined a mixture of collaboration and more traditional, hierarchical, project management. For example meetings with employed and subcontractor's foremen were used to create short term scheduling using last planner, as one foreman put it:

Foreman meeting means agreements; it's not only a schedule. We promise each other things (DKCO foreman).

However, in one of the studied projects the project managers tended to handle problems with each foreman one at a time. After testing the concept in real time, the project manager and the assistant manager found that monitoring seven healthy flows overly complex, and so they were iteratively reduced to four, and finally abandoned altogether. The company took a profound downturn when the financial crisis set in during 2008-9, due to heavy engagement in the rapidly declining residential market. Top-level management had to carry out extensive staff reductions and the support function for lean construction was seriously reduced. When top-level managers developed a new strategy focusing on public buildings and civil engineering infrastructure (i.e. roads, bridges and tunnels), the lean element was retained as subordinate to partnering pillar in the business strategy.

\section{Discussion}


The two cases of strategizing emerge along characteristically different paths of introduction and implementation. In the DK case the new OS practice is translated into praxises in a gradual and bottom up manner, whereas in the UK case the OS was sanctioned by CEO and management from the start. The Danish case shows how strategy practitioners began with a pilot project using lean construction, or more specifically last planner. This was a test even for the participants and turned out to solidify the practice and generate a first experience with strategy praxis with lean. Even if later projects went less well, the practitioners could commence promoting the new OS. However in parallel to this, another OS project focusing on scheduling was initiated by corporate strategic management. This constitutes competition for resources to the lean-practice, but more importantly made it impossible to obtain top level support for the lean solution. This only became possible at a much later stage. However the support function became interested in lean practices. The promotion of the first lean advocating project manager to become department manager was a further step forward advancing a continual enrolment of more projects into the lean OS and developing strategy praxises.

In many respects the Danish case can be considered as a typical production development project. The use of lean occurred due to a project manager's decision. Their knowledge was central to its enactment. The weekly meeting of fine scheduling was carried out with the foremen and the seven healthy streams idea was used. But in one of the studied projects the strategy practices were rendered "non-useable" by practitioners. The lack of a strong relationship between the support function and project managers may have contributed to this situation. The strategy praxis on this project possibly took this shape as the project managers (and strategy practitioners) wanted autonomy rather than counsel. The other project studied 
had a much more rigorous compliance with Last Planner as strategy practice and praxis was close to the recipe.

In the UK case, lean strategizing served to highlight the tension between the high-level corporate intensions for lean construction (as espoused by the CEO), and the actuality of sitelevel managerial practice. The case shows how an executive conceptualization of the content of lean strategy as promoting wide-ranging structural change was transformed into a more focused, more hierarchical, concentration of production efficiency measures, surveillance and monitoring procedures. As lean strategies were dispersed through training events, middle managers further modified them to make sense of their own relationships within a corporate hierarchy. The role of middle managers in the process through which an OS is implemented is revealed as significant in translating and enacting lean in ways which supported the strategic practices they had already internalized and felt comfortable guiding their strategic praxis in the training workshops: protecting their sphere of authority and applying new OS practices and standards. The inevitable distortion of the original OS ethos is not, therefore, something that can be managed or controlled by the lean champion by alternating the strategic content, or CEO at the apex of organisation. Rather it requires more careful reflection upon the significance of strategic practices (institutionalized hierarchical power relations) that guide strategic praxis (processes of strategizing) in ways that are at odds with that content. In its final enactment by site-managers, lean was constituted as a set of strategies based on a planning review meeting that strengthened power relations of the general contractor over the subcontractors. In effect, the empowering content of lean OS was more or less eviscerated through the hierarchical process of its implementation. 
In SAP terms, a range of mediating actors played a substantive role as practitioners in the praxis of strategizing lean within UKCO and DKCO. It is however clear that the two cases exhibit characteristically different paths for operation strategizing. Where UKCO creates a thorough top-down process originating from the CEO to the building projects, DKCO strategy practitioners were positioned at middle level at project level at the outset. However, both cases highlight the importance and role of middle managers as strategy practitioners (Mantere 2008). Specifically, they provide a crucial bridge, joining the strategic intent of strategic managers with the operations. Moreover, their role in enabling lateral interaction was equally important for gaining support and buy-in in the Danish case, and for enabling sensemaking processes in the top down initiative.

The ways in which middle managers mediate between others involved in the strategy enactment, and enable change and acceptance both up and down the organisation, is also clear from the cases, but their relationship to other groups of middle managers changed through the OS enactment. For example, they might be recruited to support lean from support function positions, in which case they are important for promoting the strategy practice within operations. After the sanctioning is in place, (which came late in the DKCO case) middle managers then have to find a delicate balance between the corporate strategy and involving (other) autonomous project managers. In other words, they combine important vertical and horizontal roles in mediating the space between the strategy practice and the key actors with the power to enact them. The role expectation therefore shifts over time from a more managerial administration of projects, into a change agent supporting the OS. Some project managers are inclined to follow their own strategy, creating alternative praxises even if common training and coaching is generally in place. We thus refine the delicate vertical balancing that has often has been found in the literature on middle managers (Mintzberg 1983, 
Mantere 2006), to one of having to simultaneously maintain lateral interaction between certain middle managers, department and support function managers, all of whom are central to the promotion and maintenance of the OS. Thus, project-based organizations appear provide complex arenas for middle management agency in enacting strategic practices.

In the UK case the role expectation for middle managers is clearly to back the top-down initiative. Their role in shaping and appropriating the lean strategy is all too apparent in the ways in which they reinterpret its purpose to fit the operational realities of the hierarchy that they confront. However, even here we see the lateral interaction in play, particularly in the ways in which lean was operationalized as a tool for enabling other social processes, notably hierarchical power relationships. They could also use concepts such as lean to enable improved contact and relationships with other managers who worked around them. Thus, middle management praxis revealed an aptitude in using managerial tools to enable dialogue and relations in ways that sustained the functioning of the temporary organisational setting, both within their team and across their broader supply network.

Our research also throws into relief the significant importance of middle managers, in the doing of operations strategy, for project-based organisations. Within project-based organisations, middle managers occupy a liminal status that is not simply the result of their vertical location within a command hierarchy per se, but their position between temporary and permanent organisations: the project and the head office. Our study reveals how this spatiotemporal liminality engenders them with a responsibility to strategize beyond their respective 'fiefdoms', be it staff functions, hierarchical position or projects, through building support alliances across projects, and to those in head offices looking to implement their 
particular operations strategy. The vagaries of the agency of middle managers, such as project managers, simply cannot be circumvented within these (engineering) project-based organisations - as these individuals exist both within and apart from each organisational setting, the project and the head office - by all those wishing to do operations strategy.

It could also be argued that the cases reflect the dominant management approaches in the two countries that they are derived from. The UK construction industry is often depicted as having a hierarchical top down culture, while Denmark is often thought of being a flatter more democratic management culture (Sandberg 2013). These stereotypes reflect exactly the emerging patterns found within the two cases. It should be noted, however, that DKCO corporate management followed another (top down) strategy at the time of lean entering the company. Seen in that perspective the DKCO is more a matter of timing of competing strategy practitioners and even differences in when a contractor would feel ready to embark on a contemporary strategy practice offered in the institutional environment. Also at a later occasion, the strategic turnaround following the 2008 crisis, DKCO exhibited an explicit top down strategy.

The use of the strategy as practice lens has enabled a processual view on development of Operation Strategy. Counter to most contributions on OS we were enabled to appreciate the precarious route of negotiations and interaction among a distributed set of managers, that (generally present) strategy practices, in this case lean, has to go through when transformed into organisational praxises. Space has to be left for local appropriation. Moreover the middle managers role as strategy practitioners complement senior management traditional stereotypical one as strategy makers. 


\section{Conclusion}

In this paper we have examined the role of middle managers in OS through an SAP lens within two project based engineering and production organisations. By following the formulation and implementation of a particular operations strategy, lean construction/production - as it plays out across two different organisations, we have revealed the crucial roles that middle managers play, within project-based organisations, in shaping both the journey, and the outcome. This is all the more remarkable because, as the cases show, their role and agency is just as crucial to its enactment regardless of where the operations strategy is driven from. Middle managers, including project managers, department managers, and support group managers are the key strategy practitioners contributing to the interpretation of lean construction and its embedding within organisational practice. They create support for the OS through distributed agency that at times involves lateral and vertical interaction. However, the cases of strategizing praxis in project based organisations also illustrate that these organisations follow a different path in their transformation of strategy practices; whereas in the Danish case we witness a dynamically changing role expectation of the middle managers and encouragement to experiment with what might work, the UK case reveals the role expectation as relating to maintaining, embedding, even amplifying, the initiated top down strategy project of the CEO. What unites both cases is that what is eventually constituted as lean practice is heavily reliant on the praxis of this key group of strategy practitioners.

Whereas most SAP studies highlight the recurrent role of top level managers and consultants (Jarzabkowski and Spee 2009, Rouleau 2013) this study has shown that middle managers are 
important, thereby contributing to this emerging debate within SAP studies such as Mantere (2008). The practical implication of our results are that the middle managers, their agency and interaction are far more important than most strategy literature wants us to believe and this importance is stronger in project based organisation. By mediating the space between the strategy practice and the key actors with the power to enact them they act as both the translators and enablers of strategy practice. The "middle liminality" in project based organisations is a fertile arena for strategizing, especially on operations development. Once it is recognized that strategy is (more) about doing, the implication is that the arena in the middle should be nurtured, supported and exploited in strategy formulation and implementation. This raises profound questions for the strategy process within organizations where middle management layers have been removed or reduced, not just in relation to the important vertical connections between offices and projects, but also in enabling the lateral interaction so crucial for strategy praxis. There remains a clear need to develop a deeper understanding of such middle managers' roles within project-centred organisations, particularly in relation to their role in enacting OS.

\section{References}

Anand G., Ward P.T., Mohan V., Tatikonda C., Schilling D.A. (2009) Dynamic capabilities through continuous improvement infrastructure. Journal of Operations management. 27(6), 444-461.

Ballard, G. (2000) The Last Planner System of Production Control, PhD Dissertation, School of Civil Engineering, The University of Birmingham, Birmingham. 
Balogun, J. and Johnson, G. (2004) Organisational restructuring and middle managers sensemaking. Academy of Management Journal 47(4), 523-549.

Balogun, J. and Johnson, G. (2005) From intended strategies to unintended outcomes: the impact of change recipient sensemaking. Organisation Studies 26(11), 1573-1601.

Barnes, D. (2001) Research methods for the empirical investigation of the process of formation of Operations Strategy, International Journal of Operations \& Production Management, 21(8), 1076-1095.

Betts, M., and Ofori, G. (1992), Strategic planning for competitive advantage, Construction Management and Economics, 10(6), 511-532.

Barnes, D. (2002) The complexities of the manufacturing strategy process in practice”, International Journal of Operations \& Production Management, 22(10), 1090-1111.

Boyer, K., Swink, M. and Rosenzweig, E.D. (2005) Operations strategy research in the POMS journal”, Production and Operations Management, 14( 4), 442-9. 
Bresnen, M \& Marshall, N (2000) Partnering in construction: a critical review of issues, problems and dilemmas. Construction Management and Economics, 18(7), 229-237.

Cheah C.Y.J., and Chew D.A.S., (2005) Dynamics of strategic management in the Chinese construction industry, Management Decision, 43(4), 551-567.

Cheah C.Y.J., and Garvin M.J., (2004) An open framework for corporate strategy in construction, Engineering, Construction and Architectural Management, 11(3), 176-188.

Dangayach, G.S. and Deshmukh, S.G. (2001) Manufacturing strategy - literature review and some issues, International Journal of Operations \& Production Management, 21(7) 884-932.

Davies A and Hobday M. (2005) The business of projects. Cambridge University Press, Cambridge.

De Wit, R. and Meyer, R. (2010) Strategy: Process, Content, Context, 4th ed., South-Western Cengage Learning. London.

Ekstedt, E., Lundin, R.A., Soderholm, A.,Wirdenius, H. (1999) Neo-Industrial Organising: Renewal by Action and Knowledge Formation in a project intensive economy. Routledge, London. 
Floyd, S. and B. Wooldridge (1994) Dinosaurs or dynamos? Recognizing middle management's strategic role, Academy of Management Executive, 8 (4), 47-56.

Gosling, J., Towill, D. R., Naim, M. M., \& Dainty, A. R.J. (2014) Principles for the design and operation of engineer-to-order supply chains in the construction sector. Production Planning \& Control, (ahead-of-print), 1-16.

Green, S. Larsen, G. Chung-Chin, K. (2008) Competitive strategy revisited: contested concepts and dynamic capabilities, Construction Management \& Economics, 26(1), 63-78

Hayes, R.H., Wheelwright, S.C., (1984) Restoring Our Competitive Edge: Competing Through Manufacturing. John Wiley and Sons, New York.

Helkiö P. (2013) Developing Explorative and Exploitative Strategic Intentions. Towards a practice theory of operations strategy. Aalto University Helsinki.

Hodgson D. (2002) Disciplining the Professional: The Case of Project Management. Journal of Management Studies 39 (6), 803-821. 
Jarzabkowski, P. and Spee, A. P. (2009) Strategy-as-practice: A review and future directions for the field. International Journal of Management Reviews 11(1), 69-95

Johnson, P., Balogun, J., \& Beech, N. (2010). Researching strategists and their identity in practice: Building ‘close-with’ relationships. In D. Golsorkhi, L. Rouleau, D. Seidl, \& E. Vaara (Eds.), Cambridge handbook of strategy as practice (243-257). Cambridge University Press.

Jung, D.I., Chow, C., Wu, A., 2003. The role of transformational leadership in enhancing organisational innovation: hypotheses and some preliminary findings. The Leadership Quarterly 14 (4), 525-544.

Jung, D., Wu, A., Chow, C.W., 2008. Towards understanding the direct and indirect effects of CEOs' transformational leadership on firm innovation. The Leadership Quarterly 19 (5), 582594.

Junnonen J.M. (1998) Strategy formation in construction firms, Engineering, Construction and Architectural Management, 5(2), 107 - 114

Kao, C., Green, S., and Larsen, G. (2009) Emergent discourses of construction competitiveness: localized learning and embeddedness, Construction Management and Economics, 27(10) 1005-1017.

Kentaro N. and Cusumano M.A. (1998), Thinking Beyond Lean. How Multi Project Management is Transforming Product Development at Toyota and Other companies. The Free press, New York. 
Kissi, J., Dainty, A., \& Tuuli, M. (2013). Examining the role of transformational leadership of portfolio managers in project performance. International Journal of Project Management, 31(4), 485-497.

Koch C. (2004) The Tyranny of projects - Teamworking, Organisational Knowledge and Project Management in Consulting Engineering. Economic and Industrial Democracy, 25(2), 270-292.

Koch C and Simonsen R (2006) Operations Strategy and -Innovation? -A Contractor Implementing Lean. D. Boyd (ed.): Proceedings 22th Annual Conference ARCOM conference University of Central England Birmingham. Vol 2. Pp 907-914.

Kissi, J. Dainty, A. and Tuuli, M. (2013) Examining the role of transformational leadership of portfolio managers in project performance. International Journal of Project Management, 31(4), 485-497.

Koskela. L. (2000) An exploration Towards a Production Theory and its application to Construction. Ph.D. Dissertation. VTT Building Technology, VTT publications, Espoo. 
Leong, G.K., Snyder, D.L. and Ward, P.T. (1990) Manufacturing strategy: An overview of current process and content models”, OMEGA, 18 (2), 109-122.

Lewis M.W.\& Grimes A.J. (1999) Metatriangulation: Building Theory from Multiple Paradigms. The Academy of Management Review, 24(4), 672-690.

Lycett, M., Rassau, A., \& Danson, J. (2004) Programme management: a critical review. International Journal of Project Management, 22(4), 289-299.

Löwstedt, M. och Räisänen, C. (2012) "Playing back-spin balls": Narrating organizational change in construction. Construction Management and Economics. 30 (9), 795-806

Mantere, S. (2008): Role expectations and middle managers strategic agency. Journal of Management Studies 45(2), 294-316.

Maylor, H., Brady, T., Cooke-Davies, T., \& Hodgson, D. (2006) From projectification to programmification. International Journal of Project Management, 24(8), 663-674.

Maylor H, Turner N., Murray-Webster R. (2014) It worked for manufacturing...!”: Operations strategy in project-based operations. International Journal of Project Management. Available online 18 April 2014. 
Mintzberg , H. \& Lampel, J. (1999) Reflecting on the strategy process. Sloan Management Review, Spring, 40, 21-30.

Pettigrew, A. M. (1985) The Awakening Giant: Continuity and Change in ICL. Basil Blackwell, Oxford.

Porter, M. E. (1980) Competitive Strategy. The Free Press. New York.

Rasche,A. and Chia R.(2009): Researching strategy practices: a genealogical social theory perspective. Organization studies 30 (7), 713-734

Rouleau, L. (2005) Micro-practices of strategic sensemaking and sensegiving: How middle managers interpret and sell change every day. Journal of Management Studies 42(7), 1413-41.

Rouleau L (2013) Strategy-as-practice research at a crossroads M@n@gement, 16(5), 547565.

Rouleau, L., Balogun, J. (2011) Middle Managers, Strategic Sensemaking and Discursive Competence. Journal of Management Studies. 48(5), 953-983. 
Rytter N.G., Harry Boer and C Koch (2007) Conceptualizing operations strategy processes. International Journal of Operations \& Production Management , 27(10), 1093-1114.

Räisänen, C. and Löwstedt, M. (2014) Stakes and struggles in liminal spaces: construction practitioners interacting with management-consultants. Engineering Project Organization Journal. 4(2-3), 123-133

Russell, A. Tran, N. and Staub-French, S. (2014) Searching for value: construction strategy exploration and linear planning, Construction Management and Economics, 32(6), 520-547.

Sage D, Dainty A. \& Brookes N. (2012) A 'Strategy-as-Practice' exploration of lean construction strategizing, Building Research \& Information, 40(2), 221-230.

Sandberg (ed)(2013) Northern Lights. Work Management and Welfare. SNS Förlag, Stockholm.

Sarros, J.C., Cooper, B. K., \& Santora, J.C. (2008) Building a climate for innovation through transformational leadership and organisational culture. Journal of Leadership \& Organisational Studies, 15(2), 145-158. 
Sillince, J. and Mueller F. (2007): Switching strategic perspective: The reframing of accounts of responsibility. Organization Studies. 28(2), 155-176.

Simonsen R. (2007) A management concept in Political Arenas - Lean Construction in Denmark. DTU, Lyngby.

Simonsen R. \& Koch C. (2004) Shaping Lean Construction in Project Based Organisations. Proceedings 12th. Conference International Group of Lean Construction (IGLC). Helsingør. 2004. Pp. 872-884.12p.

Simonsen, R., Bonke, S. \& Walløe, P. (2004) Management Innovation Brokers - The Story of Lean Construction Entering Denmark”. Proceedings for 12th Annual Conference in International Group of Lean Construction (IGLC), Helsingør.

Skinner, W. (1969) Manufacturing - the missing link in corporate strategy, Harvard Business Review, May/June, 136-45.

Slack, N. and Lewis, M. (2008) Strategy, 2nd Ed. Prentice-Hall, Harlow.

Stewart, R. and Spencer, C. (2006) Six-sigma as a strategy for process improvement on construction projects: a case study, Construction Management \& Economics, 24(4), 339-348 
Styhre, A., \& Josephson, P. E. (2006) Revisiting site manager work: stuck in the middle?. Construction Management and Economics, 24(5), 521-528.

Thomas, L. and Ambrosini, V. (2015) Materializing Strategy: The Role of Comprehensiveness and Management Controls in Strategy Formation in Volatile Environments, British Journal of Management, 26, S105-S124.

Thomassen, M., Sander D., Barnes K. A., Nielsen A. (2003) Experience and results from implementing Lean Construction in a large Danish contracting firm. Proceedings 11th. IGLC Virginia Tech. Blacksburg.

Whittington, R. (2001) What is strategy - and does it matter?. South-Western, Cengage Learning, 2. ed. New York.

Whittington, R. (2006) Completing the practice turn is strategy research. Organisation Studies 27(5), 613-634.

Winch G. M, (1998) Zephyrs of Creative Destruction: Understanding the Management of Innovation in Construction, Building Research and Information, 26 (5), 268-279. 